NBER WORKING PAPER SERIES

DEBT AND SENIORITY: AN ANALYSIS

OF THE ROLE OF HARD CLAIMS

IN CONSTRAINING MANAGEMENT

Oliver Hart

John Moore

Working Paper No. 4886
NATIONAL BUREAU OF ECONOMIC RESEARCH
1050 Massachusetts Avenue
Cambridge, MA 02138
October 1994

This paper is part of NBER's research program in Corporate Finance. Any opinions expressed are those of the authors and not those of the National Bureau of Economic Research.

(c) 1994 by Oliver Hart and John Moore. All rights reserved. Short sections of text, not to exceed two paragraphs, may be quoted without explicit permission provided that full credit, including () notice, is given to the source. 


\section{DEBT AND SENIORITY: AN ANALYSIS \\ OF THE ROLE OF HARD CLAIMS \\ IN CONSTRAINING MANAGEMENT}

\section{ABSTRACT}

We argue that long-term debt has a role in controlling management's ability to finance future investments. A company with high (widely-held) debt will find it hard to raise capital, since new security holders will have low priority relative to existing creditors. Conversely for a company with low debt. We show there is an optimal debt-equity ratio and mix of senior and junior debt if management undertakes unprofitable as well as profitable investments. We derive conditions under which equity and a single class of senior long-term debt work as well as more complex contracts for controlling investment behavior.

Oliver Hart

Department of Economics

Littauer Center 220

Harvard University

Cambridge, MA 02138

and NBER
John Moore

London School of Economics

Houghton Street

London WC2A 2AE

UNITED KINGDOM 
Since the time of Modigliani and Miller's famous irrelevance theorem. economists have devoted wuch effort to relaxing the theorem's assumptions in order to understand the real-world trade-offs between debt, equity and other corporate financial instruments. In particular, Ilteratures have developed that explain the issuance of debt by public companies as an attempt to reduce taxes (see, e.g., Franco Modigliani and Merton Miller (1963) and Miller (1977)): as a signalling device (see, e.g.. Hayne Leland and David Pyle (1977) and Stephen Ross (1977)); as a way of completing markets (see, e.8., Joseph Stiglitz (1974) and Franklin Allen and Douglas Gale (1988)): and as an attempt to raise funds without diluting the value of equity (see Stewart Myers and Nicholas Majluf (1984)). 1

While each of these approaches has provided important insights, none has been entirely successful in explaining the choice of financial structure. In particular, these approaches cannot explain the types of debt claims obsorved in practice. As one of us has argued elsewhere. (see Oliver Hart (1993)). under the maintained hypothesis of most of the literature that management is not self-interested, the first-best can be achleved by making all of a firm's debt soft; that is, all debt should be Junior (management should be given the right to issue unlimited amounts of additional debt senior to existing debt) and postponable (all debt should be in the form of payment-in-kind (PIK) bonds, which giv: !unagement the right to postpone debt payments at management's direction). The reason is that, by issuing such soft claims, the firm can take advantage of all the tax and market completion benefits of debt without incurring any bankruptcy or financial distress 
costs. Efficient investment cholces can be ensured by putting management on an Incentive scheme that rewards it according to the firm's total (net) market value, rather than Just the value of equity. Such an Incentive scheme also avolds conflicts of interest between shareholders and creditors (of the type stresed by Michael Jensen and WIIIIam Meckling (1976)). 2

In reality, firms issue considerable amounts of "hard" (senior, nonpostponable) debt. ${ }^{3}$ That is, we do not appear to Ilve in the Ideallzed world described above. Presumably, the reason is that managers are self-Interested in practice (in this paper, we do not distinguish between management and the board of directors). Among other things, managers have goals, such as the pursuit of power and perquisites, that are not shared by investors. "Hard" debt then has an important role to play in curbing managerial excess. 4 First, nonpostponable, short-term debt forces managers to disgorge funds that they might otherwise use to make unprofltable but emplite-building investments, and to trigger liquidation in states of the world where the firm's assets are more valuable elsewhere. Second, sentor Iong-term debt prevents managers from financing unprofitable investments by borrowing against future earnings. Hard debt may be put in place elther by the company's founders before the company goes public, or by management itself in response to a hostile takeover bid.

The role of short-term debt in forcing management to disgorge free cash flow has been stressed by Jensen (1986), although he does not analyze it formally.s In addition, Jensen emphasizes the benefits of debt, but has little to say about the costs. The role of long-term debt in constraining self-interested management from raising new capital has not been 
analyzed at all, as far as we know. The purpose of this paper is to provide an analysis of the costs and benefits of debt, with a particular emphasis on long-term debt.

He consider a public company, consisting of assets in place and new Investment opportunities (along the Ilnes of Myers (1977): in Kyers' work. however. management is not self-interested). The company's security structure is chosen at date 0 , an investment decision is made by management at date 1 , and funds are pald out to investors at date 2 (there is symetric information throughout). We assume that management's emplre-buliding tendencles are sufflclently strong that it will always undertake the new investment if it can, even if the investment has negative net present value. In order to focus on the role of long-term debt, we assume that the flrm's going concern va'le exceeds its liquidation value, and that the company's date 1 earnings are insufficient to finance the Investment internally. Under these assumptions, we show that the optimal level of short-term debt is zero. However. (senlor) long-term debt is important in constraining management's ability to ralse new funds. The trade-off for investors is the following. If the company has 11 ttle or no long-term debt, management w111 find it easy to finance some negative net present value projects by borrowing against (that is, dlluting) future earnings from assets in place. That is, there will be overinvestment. On the other hand, If the company has a large amount of senior long-term debt, management w1ll be unable to finance some positive net present value projects because earnings from assets in place are over-mortgaged (there is debt-overhang in the sense of Myers (1977)). That Is, there w\$1 be underinvestment. 
We use this trade-off to determine the company's optimal debt-equity ratio and to derlve a number of comparative statils results concerning the relationshlp between the debt-equity rat10 and the mean and ex ante varlance of the return on assets in place and on new investments. 6 In fact, it turns out that it is sometimes optimal for the company to 1 ssue a more sophisticated set of claims than Just senior debt and equity; in particular, to issue classes of debt of different senloritles. With covenants allowing (limited) dilution of each class. This is observed in practice and is analyzed in the paper. Finally. we show that our theory is consistent with the "two most striking facts about. corporate finance" (see Myers (1990)): profltablifty and financlal leverage are negatively correlated, and increases In leverage ralse market value.

It is useful to note some aspects of our theory of debt that distinguish it from other agency theorles in the literature. First, in most of the literature, debt is equivalent to an incentive contract with management of the form: "If you (the manager) do not pay $D_{t}$ dollars to security-holders at date $t$, then the company goes bankrupt, 1.e. you lose your job." Given this, it is uncleár w'i; an incentive contract of this form would not be employed directly. In contrast, in our model; debt is not equivalent to a contingent firing. Rather, debt regulates the manager's ablilty to ralse capital, making this sensitive to new information avallable to the market at date 1 when investment decisions are taken. Since we suppose this information to be observable but not veriflable, there is no standard Incentive scheme that duplicates the optlmal debt contract.

Second, much of the literature derives the optimal debt-equity ratio 
under the assumption that the company can issue only standard debt and equity claims. In contrast, Section III considers the case where the company can issue arbitrary claims (In some cases we show that the extra degree of freedom $\mathbf{W 1 1}$ not be used). Thus the paper can be seen as a contribution to the emerging literature on optimal security design (see the recent survey by Harrls and Raviv (1992)).

The paper is organized as follows. In Section I, we lay out the basic model, and obtain a sufficient condition for the optimal level of short-term debt to be zero. Section II contains a number of results about the optimal level of long-term debt. In Section III, we consider more general security strictures. Finally, Section IV concludes.

\section{The Model}

We use the following model, first laid out by Myers (1977).

Consider a firm consisting of assets in place and new investment opportunities, which exists at three given dates (see Figure 1).

FIGURE 1 NEAR HERE

At date $O$ the firm's financial structure is chosen. At date 1 the assets in place yleld a return of $y_{1}$ and a new investment opportunity costing 1 
appears. At this time, the firm can be liquldated, ylelding $L$ (In addition to the $y_{1}$ already realized). We take both investment and liquidation to be zero-one decisions. If the firm is not liquidated, at date 2 the assets in place yield a further return $y_{2}$ and the new investment opportunlty -- if it was taken at date 1 -- yields $r$. At this date the flrm 18 wound up. and recelpts are allocated to securlty holders.

The firm is run by a single manager. This manager decldes whether to take the new investment opportunity. The varlables $y_{1}, y_{2}, 1, r, L$ are typically uncertaln as of date 0 ; however, thelr probabillty distribution is cortion knowledge. All uncertalnty about $y_{1}, y_{2}, 1, r$ and $L$ is resolved at date 1 , and there is symetric information throughout. However, $y_{1}, y_{2}, 1, r$ and $L$, although observable, are not veriflable. In other words, these variables cannot be the basis of an enforceable, contingent contract. ${ }^{7}$ Assume also, for simplicity, a zero interest rate, and that investors are risk neutral.

Al though $y_{1}, y_{2}, 1, r, L$ are not veriflable, we suppose that the total amount paid out to security-holders is verifiable. Thus securlties can be issued at date 0 with claims conditional on the amount that is pald out. However, we do not allow clalms to be issued on the return from the Investment. $r$, separately from the return from the assets in place, $y_{2}$; that 1s, we rule out project financing. ${ }^{8}$ Untll section III, we shall confine attention to the case where the firm issues short-term debt due at date 1. long-term debt due at date 2, and equlty; and for the time belng we shall suppose that both kinds of debt are senior, In the sense that any new claims issued by the f $1 \mathrm{rm}$ at date 1 are entitled to payment only if date 0 
debt-holders have been fully pald off. In Section III, we wIll Investigate the role of more sophlsticated securities.

We also assume that it is prohibitively costly for the firm to renegotiate with creditors at date 1 . Thus $1 f$ the firm defauls on 1 ts short-term debt at date 1, then this triggers bankruptcy, which, In turn. leads to llquidation: 1.e.. L 1 s reallzed. 9 (We discuss the no-renegotiation assumption further in Section IV.,

$$
\text { As emphasized earlier, we are interested in a situation }
$$

where management may carry out some investment projects for power or emplre-bullding reasons even though they are unprofitable. ${ }^{10}$ To slmplify, we consider the (admittedly) extreme case where the emplre-buliding motive is so strong that no feasible financlal Incent1ve payment can persuade the manager not to Invest at date $1 .^{11}$. At the same time we suppose that the manager's emplre-bullding tendencles are $11 \mathrm{mlted}$ io a single, Indivisible project. That 1s, once the project is financed, the manager has no further uses for company funds, i.e. he (or she) cannot or does not wish to employ such funds to make additional investments or to pay for perks or higher salarles (one interpretation is that perks and salaries are adequately controlled by other mechanisus, e.g., incentive schemes). 12

Given these assumptions about emplre-building behavior, the only way to stop the manager from Investing in the project is to prevent the necessary funds from belng made available at date 1 . We also suppose that the manager never Ilquidates the firm voluntarlly at date 1. since this involves a loss of power. In contrast, at date 2 there are no Investment opportunltles and 
so the manager is wllling to pay out all accurulated funds (one Interpretation is that the manager retires and the firm is wound up at date 2).

The financlal structure of the firm is chosen at date 0 so as to maximize the aggregate expected return of the security holders; $1 . e$. to maxlmize the $f 1 \mathrm{rm}^{\prime} s$ date 0 market value. This may seem an odd assumption given that financial structure decisions are typically made by management (or the board of directors), and we have supposed management to be self-interested. The assumption can be Justified in two ways. First, the financial structure cholce may be made, prior to a public offering at date 0. by an orlginal owner, who wishes to maximize his total recelpts in the subsequent offering (he is about to retire). Second, one can Imagine that the firm is initially all equity, and the threat of a hostlle takeover at date 0 forces management to choose a new financial structure which maximizes date 0 market value (the hostile bldder is present now. but may not be around at date 1 . So management must bond 1 tself now to act well in the future). 13

Def ine $d_{1}$ to be the amount owed at date 1 , and $d_{2}$ to be the amount owed at date 2 - 1.e.. $d_{1}$ and $d_{2}$ are the face values of short-term and long-term debt respectively. (of course, at date 0 these debt claims will typically trade for less thain their face value because of the risk of default.) In general, the instruments $d_{1}$ and $d_{2}$ have distinct roles in curbing the manager's empire bullding tendencles. Since the role of short-term debt is relatlvely well understood, In thls paper we concentrate on the role of long-term debt. To this end, we now present an assumption whlch Implies that it is optimal to set $d_{1}=0$. 
(Al) says that the manager can never finance the Investment out of date 1 earnings (there is no free cash flow) and that it is never efficlent to liquidate the flrm at date 1 . (Al) may be plausible for the case of a growth company that, at least inftially, requires an injection of new capltal to prosper.

To understand why (AI) Implies that the optimal $d_{1}$ is zero, consider the situation facing the manager at date 1 . Given the manager's empire-buiding tendencies, his first choice is to invest (If he can ralse the funds). His second cholce is to malntain the firm as a golng concern (if he can't Invest, but can pay off his date 1 debts). His third choice is to close the firm down (he does this only if he 1s forced to default at date 1 and go bankrupt).

Now the firm's total revenues if the manager invests are $y_{1}+y_{2}+r$. of which $d_{1}+d_{2}$ is mortgaged to the old (senlor) creditors. (Recall that all uncertainty is resolved at date 1.) Hence the most the firm can borrow at date 1 is $y_{1}+y_{2}+r-d_{1}-d_{2}$. It follows that the manager w11l invest if and only if

$$
y_{1}+y_{2}+r-d_{1}-d_{2}=1
$$


If (1) Is satisfled, the total return to date 0 claim-holders, $R$, is

$$
R=y_{1}+y_{2}+r-1 .
$$

of which date 0 creditors recelve $d_{1}+d_{2}$ and shareholders recelve the rest.

Notice for future reference the two sources of inefficiency here.

Sometimes the manager will invest even though $r<1$, because $y_{1}+y_{2}$ is blg relative to $d_{1}+d_{2}$. Othertimes he wili be unable to Invest even though $r>$ 1 , because $y_{1}+y_{2}$ is small relative to $d_{1}+d_{2}$.

If (1) is not. satisfied, the manager will be able to maintain the firm as a golng concern as long as

$$
\text { elther } y_{1} \geq d_{1} \text { or } y_{1}+y_{2} \geq d_{1}+d_{2} \text {. }
$$

In the flrst case, the manager pays the date 1 debt out of current earnings, while, in the second case, he pays it by borrowing out of future earnings. If (3) but not (1) Is satisfled, the total return to date 0 claim-holders is 


$$
R=y_{1}+y_{2}
$$

Finally, if neither (1) nor (3) is satisfled, the firm is Ilqu ldated at date 1 and

$$
R=y_{1}+L .
$$

It should now be clear why $d_{1}=0$ is optimal; that is, why $d_{1}=0$ maximlzes the expected value of $R$. Only the sum $d_{1}+d_{2}$ matters in (1) and the second half of (3). However, a low $d_{1}$ is good in increasing the chance that the first half of (3) is satisfled, 1.e. minimizing the likellhood of liquidation (liquidation is undesirable since, given $y_{2} \geq L$, (4) and (5) imply that $R$ is higher when the firm survives than when it is (1quidated).

We have therefore established

\section{Proposition 1}

Assume ( $A 1$ ). Then the date $O$ market value of the firm is maximized by setting $d_{1}=0.14$

In the next section, we analyse the optimal level of long-term debt. 


\section{Long Term Debt}

For the remainder of the paper we assume that ( $A 1$ ) holds, and so, by Proposition 1, the optimal $d_{1}$ is zero. Thus liquidation never occurs at date 1 and $L$ is irrelevant.

Denote by $F\left(y_{1}, y_{2}, 1, r\right)$ the probabllity distribution of $y_{1}, y_{2}, 1$ and $r$. as of date 0 . The return from the existing assets,

$$
\int\left(y_{1}+y_{2}\right) d F\left(y_{1}, y_{2}, 1, r\right) .
$$

is flxed, and so in evaluating the effects of different levels of $d_{2}$ we can focus on the net soclal return from the new investment, $r-1$. From (1), we know that the investment goes ahead if and only if $y_{1}+y_{2}+r-1 \geq d_{2}$; and so an optlmal $d_{2}$ solves:

(6)

$$
\max \operatorname{lmlze} \underset{y_{1}+y_{2}+r-i z d_{2}}{ }(r-1) d F\left(y_{1}, y_{2}, 1, r\right) .
$$

The basic tradeoff is the following. The benefit of a high $d_{2}$ is that t. returns from the assets in place are mortgaged, whlch stops management 
from using them to subsidize bad investment projects. The cost of a high $\mathrm{d}_{2}$ 1s debt overhang: given that new Investors' clalms are junlor to the debt $d_{2}$. good projects cannot be undertaken if returns frow existing assets are ovirsortgaged. An optimal $d_{2}$ strikes the right balance between these two conflicting objectives.

There are four cases in which it is possible to obtain the first-best; these are grouped in Proposition 2.

\section{Proposition 2}

(1) If $r$ is greater than 1 with probabllity 1 , then the first-best can be achieved by setting $d_{2}$ equal to o (all equity).

(2) If $r$ is less than 1 with probabllity 1 , then the flrst-best can be achieved by setting $d_{2}$ large enough.

(3) If $y_{1}+y_{2}$ equals some constant $\bar{y}$ with probablịty 1, then the first-best can be achleved by setting $d_{2}$ equal to $\bar{y}$.

(4) If 1 and $y_{1}$ are deterministic, and $r \equiv g\left(y_{2}\right)$ where $g($.$) is a strictly$ increasing function, then the first-best can be achleved by setting $d_{2}$ equal to $y_{1}+g^{-1}(1)$.

Part (1) of Proposition 2 is 1mmediate. Since there is no danger of the 
manager maklng an unprofltable investment. It is best to glve him the flexibllity to ralse as much money as he can at date 1 , by having no debt. The Investment then always goes ahead, as requlred in the flrst-best. Part (2) Is the opposite extreme, where no Investment is ever prof Itable. The effect of a large amount of senlor (nondllutable) debt $d_{2}$ is that the manager is never able to ralse further funds at $t=1$, and so the Investment never goes ahead.

Part (3) reveals quite a lot about the economics of the model. The difficulty faced by those designing the security structure at date 0 is that the uncertaln returns $y_{1}+y_{2}$ from exlsting assets cannot be disentangled from the uncertain returns $r-1$ from new investment. As a result, there is a danger that the manager will be able to flnance the new Investment at date 1 by borrowing against $y_{2}$. However, the danger can be avolded if the total return $y_{1}+y_{2}$ from existlng assets is flxed, because thls return can be mortgaged away at date 0 by lssuing senlor, nondllutable debt. The manager then invests if and only if $r$ is greater than 1 . One polnt to observe here is that the debt $y_{1}+y_{2}$ Is rlskless; however, thls does not mean that it does not play an important role in preventing the manager from making unprofitable investments.

Part (4) is àlso revealing. If $r E g\left(y_{2}\right)$, and $\&$ and $y_{1}$ are deterministic, then it is again possible In effect to disentangle the returns from the existing assets and returns from the new Investment. GIven $d_{2}=y_{1}$ $+g^{-1}(1)$, the manager invests if and only if $y_{2}+r$ exceeds $1+g^{-1}(1)-$ $1 . .$. since $r \equiv g\left(y_{2}\right)$. if and only if $r$ is greater than 1 . 
In general the first-best cannot be achleved. Some insight into the second-best can be obtalned by differentiating (6). If $F$ is a continuous distribution, we can express the first-order condition for an interior opt lium as

$$
E\left[r-1 \mid y_{1}+y_{2}+r-1=d_{2}\right]=0
$$

That 1s, $d_{2}$ is set at a level such that in marginal investment project just breaks even.

We consider next some comparative static propertles. Proposition 3 below shows how $d_{2}$ changes with the means of $y_{1}, y_{2}, 1$ and $r$. Part (2) of the Proposition uses the following condstion.

Condition $C$ The left hand side of $(7), E\left[r-i \mid y_{1}+y_{2}+r-1=d_{2}\right]$. is continuously differentiable on an interval $\left[d_{2}, \bar{d}_{2}\right]$. Moreover, Whenever ( 7 ) holds, it is also the case that

$$
0<\frac{\partial}{\partial d_{2}} E\left[r-1 \mid y_{1}+y_{2}+r-1=d_{2}\right]<1 .
$$

$$
\text { Denote } r-1 \text { by } X \text { and } y_{1}+y_{2} \text { by } Y . \quad \text { (8) says that } E\left[X \mid X+Y=d_{2}\right]
$$
increases with $d_{2}$, but by less than the amount $d_{2}$ increases. Note that the 
left hand Inequality in Condition $C$ is simply the second order condition for $d_{2}$ In $(6)$, whlch wlll hold (albelt weakly) If $(r-1)$ and $\left(y_{1}+y_{2}+r-1\right)$ are afflllated (that is, In a loose sense, positively correlated; see Paul Mllgrom and Robert Weber (1982), Theorem 5). The rlght hand Inequallty will hold If, In addition, $\left(y_{1}+y_{2}\right)$ and $\left(y_{1}+y_{2}+r-1\right)$ are afflllated.

\section{Proposition 3}

Suppose $d_{2}$ is an opt lmum debt level.

(1) If a dollar is added to every reallzation of $y_{1}$. or added to every reallzation of $y_{2}$, then $d_{2}+1$ is a new optlmum debt level.

(2) Assume that Condition $C$ holds, and that $d_{2}$ is an interlor optimum in $\left[\underline{d}_{2} \cdot \bar{d}_{2}\right.$ ] (In whlch case it is unlque). If a small amount is added to every reallzation of 1 , or subtracted from every reallzation of $r$, then the optlmum debt level strlctly increases.

Proposition 3 is proved in the Appendix. The intultion is stralghtforward. An Increase in $y_{1}$ gives the manager more cash with whlch to lnvest at date 1, and so at the margin hls ablllty to borrow should be cunitralned: the debt level should rise. Equally, an Increase in the mean of $y_{2}$ Implles that the manager can borrow more at date 1 agalnst the return from the existing assets, and so, agaln, the debt level should rise. An Increase In the mean of 1 , or a decrease in the mean of $r$, Implles that Investments 
are less 11kely to be prof 1 table, and therefore the manager should be constrained with higher debt.

Notice that part (1) of the Proposition says that $d_{2}$ in fact moves dollar-for-dollar with increases in $y_{1}$ or $y_{2^{*}}$. Thls follows directly from an Inspection of program ( 6 ): If a dollar is added to every realization of $y_{1}$ (or $y_{2}$ ) and a dollar is added to $d_{2}$, thon the set of states in whlch Investment goes ahead is unchanged (and the return from investment, $r-1$, is also unchanged).

There are no comparably general results for how the optlmal $\mathrm{d}_{2}$ changes with the varlances of $y_{1}, y_{2}, 1$ and $r$. However, It is easy to compute the optimal $\mathrm{d}_{2}$, and therefore to see the variance effects, in two examples. These examples also 1llustrate the mean effects from Proposition 3 . For simplicity, in both examples we assume that $y_{1}$ and 1 are deterministic (w1th $\left.y_{1}<1\right)$

\section{Example 1}

$\mathrm{y}_{2}$ and $\mathrm{r}$ are independently and normally distrlbuted with means $\mu_{2}, \mu_{r}$ a)i varlances $\sigma_{2}^{2}, \sigma_{\sigma^{\prime}}^{2} 15$ Then by standard distribution theory the LHS of (7) is simply

$$
\mu_{r}-1+\left(\frac{\sigma_{r}^{2}}{\sigma_{r}^{2}+\sigma_{2}^{2}}\right)\left[d_{2}-y_{1}-\mu_{2}-\mu_{r}+1\right] i
$$


and hence the optimal debt level $d_{2}$ is

$$
d_{2}=y_{1}+\mu_{2}-\frac{\sigma_{2}^{2}}{\sigma_{r}^{2}}\left[\mu_{r}-1\right] \cdot 16
$$

Example 2

$y_{2}$ and $r$ are independently and unlformly distributed on $\left[\mu_{2}-s_{2}, \mu_{2}+s_{2}\right]$, $\left(\mu_{r}-s_{r} \cdot \mu_{r}+s_{r}\right)$ respectively. Assume that $\mu_{r}-s_{r}<1<\mu_{r}+s_{r}$ (otherwise, by Propositions $2(1)$ and $2(2)$, the optimal $d_{2}$ would be elther zero or Infinity). Also, to simplify the example, we assure that $s_{r}<s_{2}$.

There are two cases to consider: (a) the case where on average new Investment is profitable $\left(\mu_{r}>1\right)$; and (b) where it is unprofitable $\left(\mu_{r}<1\right)$.

In case (a), the optimal debt level $d_{2}$ is indicated in Figure 2 -where the support of $y_{1}+y_{2}$ is the horlzontal of the rectangle, and the support of $r-i$ is the vertical (note that, since $s_{r} \cdot<s_{2}$, the rectangle is wider than it is tall). Notice that conditional on $\left(y_{1}+y_{2}\right)+(r-1)=d_{2}$ -- i.e. conditional on lying along the $135^{\circ}$ line intersecting the rectangular support -- the expectation of $r-1$ is zero, as required by (7).

FIGURE 2 NEAR HERE. 
From the figure it is clear that the optlmal debt level must satisfy $d_{2}-\left(y_{1}+\mu_{2}-s_{2}\right)=-\left(\mu_{r}-s_{r}-1\right)$; that $1 s$,

$$
d_{2}=y_{1}+\mu_{2}-s_{2}-\mu_{r}+s_{r}+1
$$$$
\left(\mu_{r}>1\right)
$$

In case (b), a similar line of reasoning leads to

$$
d_{2}=y_{1}+\mu_{2}+s_{2}-\mu_{r}-s_{r}+1 . \quad\left(\mu_{r}<1\right)
$$

In both Examples 1 and $2, d_{2}$ rises with $y_{1}$, rises with the mean of $y_{2}$, falls with 1, and rises with the mean of $r--$ all as per Proposition 3. Also, if new investment is on average profitable (1.e., $\left.\mu_{r}>1\right)$, then $d_{2}$ falls with the variance of $y_{2}$, and rises with the variance of $r$. However, if new investment is on average unprofitable $\left(\mu_{r}<1\right)$, these variance effects are r:iersed: $d_{2}$ rises with the variance of $y_{2}$, and falls with the varlance of $r$.

To understand the variance effects better, note that, in problem (6). $d_{2}$ is set so that the market's assessment of future total return at date 1 screens the quality of new investment appropriately. If $y_{1}$ and 1 are constant (as in Examples 1 and 2), the first-order condition (7) says that the conditional expectation of $r, E[r \mid ; r=P]$, wust equal i when $P=d_{2}+1-$ $y_{1}$. Now as the variance of $y_{2}, \sigma_{2}^{2}$, rises relative to the variance of $r, \sigma_{r}^{2}$, 
the fact that $y_{2}+r=d_{2}+1-y_{1}$ reveals less Information about $r-1$ (we are looking at this from date 0 , when $r$ and 1 are uncertaln). In the 1 imit as $\sigma_{2}^{2} \rightarrow \infty$ or $\sigma_{r}^{2} \rightarrow 0$, the LHS of $(7)$ becomes slmply $\mu_{r}-1$, and the optimum w11 not be interior. In the case where new Investment is on average profitable $\left(\mu_{r}>1\right)$, it is best to give the manager maxlmum freedom to finance new investment; 1.e. to set $d_{2}=0$. In the case where new investment is on average unprofitable $\left(\mu_{r}<1\right)$, it is best to give the "manager no freedom to finance new investment; 1 .e. to set $d_{2}=\infty$. Put slmply, if the manager's abllity to ralse fresh capital at date 1 is almost entlrely determined by the reallzed returns from existing assets, then there is little point in using a security structure to screen out the bad new investments. One may as well rely on prior (date 0) Information -- 1.e. whether or not new Investments are on average profitable.

Since the above intultion for the varlance effects does not hinge on the particular distributional assumptions of Examples 1 or 2, we suspect that It may be possible to establish a general result about the effects of increasing variance. He do not have such a result to report at this time, however.

III. General iong-Term Security Structures

In this section, we explore the possibility that more sophisticated long-term security structures than sl:f.:- debt may be optimal. He start by laying out a quite general class of security structures, and give an example 
showing how the extra degrees of freedom help. The kind of securities we Introduce may at first sight seem rather forelgn: but we'go on to show that they can be approximated by a conventlonal class of debt contracts based on seniority. The section ends by conside-:ing under what clrcumstances one would not need the additional flexibility offered by our general security structure, and could instead merely rely on simple debt and equity (as in Section II).

Recall that al though $y_{1}, y_{2}, 1, r$ are not veriflable, the total amount paid out to security-holders at date 2 , denoted by $P$, is verifiable. Thus securlties can be issued at date 0 with claims conditional on $P$. The most general long-term security structure consists of contingent debt, along the following lines. The firm issues a single class of securitles at date 0 with an (enforceable) promise that if $P$ dollars are distributed at date 2 , this class will collectively recelve $O(P)$ of them, where $O \leq O(P) \leq P$. (The " $O$ " in $O(P)$ denotes the old, or original, date o security holders.) In addition. management is given permission to issue any new securitles it likes at date 1. That is, management can earmark the residual amount $N(P) \equiv P-O(P)$ for new investors at date 1 in the attempt to finance new investment. (The " $N$ " in $N(P)$ denotes the new Investors at date 1.) Note that a cholce of $O(P)$ close to or far away from $P$ at date 0 constrains the firm more or less in its investment choice at date 1.17

General long-term securities 11ke $O(P)$ are not, to our knowledge, observed. However, we show shortly that, under two mild assumptions, any cholce of $O(P)$ is equivalent to a packipe of "standard" securities, consisting of equity and varlous senlorities of debt. Thus for the moment we 
stick with the general specification $O(P)$. We continue to assume (A1) throughout this section. ${ }^{18}$

Given $N($.$) (or equivalently O($.$) ), consider the position of management$ at date 1 once $\left(y_{1}, y_{2}, 1, r\right)$ are realized. Since $y_{1}$ is less than 1 , the manager can Invest only if he can ralse $1-y_{1}$ from the market. If he does Invest, $P=r+y_{2}$, and so the most he can offer the market at date 2 is $P$ $O\left(r+y_{2}\right)=N\left(r+y_{2}\right)$. It follows that the manager will be able to finance the investment if and only if $\mathrm{N}\left(r+\mathrm{y}_{2}\right) \geq 1-\mathrm{y}_{1}$.

As in (6), an optimal security structure at date 0 is represented by a function $N(P)$, which solves:

$$
\begin{aligned}
& \underset{N(.)}{\operatorname{Maximize}} \int_{N\left(r+y_{2}\right) \geq 1-y_{1}}(r-i) d F\left(y_{1}, y_{2}, 1, r\right) \\
& \text { subject to } \\
& 0 \leq N(P) \leq P .
\end{aligned}
$$

So far we have allowed the slope of $N(P)$ to be almost arbitrary. With a minor modification in the manager's set of avallable actions, however, we can restrict $N$ to have a slope betweer. 3 3ro and one. Assume that the manager can comit himself at date 1 to lower the return both of the investment project and of the assets in place, e.g. by seliling of some fraction of the 
assets at an artificlally low price or by hiring extra workers. Suppose that $N\left(P^{-}\right)>N\left(P^{+}\right)$for some $P^{-}<P^{+}$. Then tha $\| 1 r^{*}$ s date 0 market value can only increase if $N\left(P^{+}\right)$is ralsed to equal $N\left(P^{-}\right)$. The reason is that the low value of $\mathrm{N}\left(\mathrm{P}^{+}\right)$cannot be effective in deterring management from investing. since if $y_{2}+r=P^{+}$and $N\left(P^{+}\right)<1-y_{1} \leq N\left(P^{-}\right)$, the manager w11l ralse the $\left(1-y_{1}\right)$ dollars necessary to invest by comitting himself to lower total return from $\mathrm{P}^{+}$to $\mathrm{P}^{-}$. Thus if $N\left(\mathrm{P}^{+}\right)$is ralsed to $N\left(\mathrm{P}^{-}\right)$, the same investment decisions occur but total return is generally higher since the manager is not encouraged to engage in wastage. An extension of this argument shows that date 0 market value can only increase if $N(P)$ is replaced by $\sup \left\{N\left(P^{-}\right) \mid P^{-} \leq P\right\}$ for each $P$. This ylelds a monotonically increasing function $N(P)$.

A simllar argument shows that the slope of $\mathrm{N}$ can be set less than or equal to one, if the manager can always ralse more funds than he needs for the Investment project and save the rest at the golng rate of interest. ${ }^{19}$

From now on, therefore, when we solve for the optimal security structure we 1mpose the extra constraint that $N$ has slope between 0 and 1:

$$
0 \leq N\left(P^{+}\right)-N\left(P^{-}\right) \leq P^{+}-P^{-} \quad \text { for all } P^{-} \leq P^{+} \text {. }
$$

Is all the flexiblilty afforded by this general security structure useful? Example 3, which generalizes Proposition 2(4) to the case of uncertain 1, shows that indeed it is. 
Example 3

Suppose $y_{1} \equiv 0$, and $r$ E $g\left(y_{2}\right)$, where $g($.$) is a strictly increasing$ function. Then one can obtain first-best by putting $N(P)=N$, the (unique) solution to

$$
N+g^{-1}(N)=P
$$

(It is stralghtforward to confirm that (13) and (14) hold.) For a given $r$ (and hence $y_{2}=g^{-1}(r)$ ), the manager can raise up to $N\left(r+y_{2}\right)$ to finance the Investment. But by construction, $N\left(r+y_{2}\right)=r$. Moreover, since $y_{1}=0$, the manager needs to raise the full cost 1 to make the investment -- which means he will be in a position to invest if and only if $r \geq 1$ (1.e. the first-best Is Implemented).

Our next task is to show that our general security structure $N(P)$ can be represented by a "standard package" of securities, comprising equity and noncontingent debf of various seniorities.

A standard package of debt and equity consists of $n$ classes of debt and a single class of equity. The Jth class of debt, $J=1, \ldots, n$, is characterized by an amount $D^{J}$ collectively owed to class $\mathrm{J}$ at date 2 and a maximum additional amount $\Delta D^{J}$ of indebtedness to class $J$ that the firm can 
take on at date 1 (1.e. a covenant in the initial debt contract allows the firm to issue new debt at date 1 until the total amount owed class $J$ is $D^{j}+$ $\Delta D^{j}$ ). The classes are ranked by senlority with 1 being the most senlor (In the sense that it must be paid off first) and $n$ the most junlor. The firm can create an $(n+1)^{\text {th }}$ class of debt of any size at date 1. which is junior to all existing debt, but senior to equity: in effect, $\Delta^{n+1}=\infty$.

Th1s description of debt is consistent with what we observe in practice. Firms do issue securities of different seniorities -- the typlcal order being secured debt, then varlous priority clalms, then unsecured debt. then subordinated debt, and finally equity. Moreover, firms retain the right to issue further securities of comparable or higher senlority, but within prespecifled llmits. For secured debt, these limits w111 be determined by the amount of collateral still avallable; and also possibly by a negative ples.je clause, which prohlbits the issuance of any new debt with a superior claim to existing unsecured debt or which requires that unsecured creditors be ralsed to equal status with subsequent claims. For unsecured debt, the freedom to issue further debt is of ten constrained by covenants specifying upper $11 \mathrm{mlts}$ on the ratio of debt to net worth or to tanglble assets. 20

Let us now consider the shape of $r_{i}$. function N(P) for the above package of standard debt and equity. Suppose at date 1 the firm issues all the additional debt $\Delta D^{1}, \ldots, \Delta D^{n}, \Delta D^{n+1}$ that it is permitted to under the date 0 covenants. How much will these varlous new issues fetch? Suppose it Is known at date 1 that the firm's date 2 pay-out w1ll be $P$. For $0 \leq P \leq D^{1}$ $+\Delta D^{1}$. only the most senior class of creditors recelve any payment, and the slope of $N(P)=\Delta D^{1} /\left(D^{1}+\Delta D^{1}\right)$; the point is that, In this region, at date 2 
every dollar of $P$ is divided in the proportions $\Delta D^{1}: D^{1}$ between new and old class 1 creditors. For $D^{1}+\Delta D^{1}<P \leq D^{1}+\Delta D^{1}+D^{2}+\Delta D^{2}$, the slope of $N(P)$ $=\Delta D^{2} /\left(D^{2}+\Delta D^{2}\right)$. Here, at date 2 class 1 creditors (old and new) are fully pald, and every dollar of the residual, $P-D^{1}-\Delta D^{1}$, is divided in the proportions $\Delta D^{2}: D^{2}$ between new and old class 2 creditors; more junior creditors recelve nothing. And so on ... See Figure 3.

FIGURE 3 NEAR HERE

It follows from Figure 3 that a standard debt/equity package yleids a particular function $N(P)$ that satisfies (13) and (14). It is also clear from figure 3 that the converse holds, at least approximately: given any function $N(P)$ satisfying (13) and (14), we can find a standard debt/equity package that approximately implements it. Simply approximate the curve $N(P)$ by a plecewise linear graph whose slope always 1 les between 0 and 1 . Such a piecewise Ilnear graph is a representation of some standard debt/equity security package.

The leading example of a standard package is the case of simple debt/equity, which we examined in Section II. Namely, there is a single class of debt that cannot be diluted: $n=1, D^{1}>0$, and $\Delta D^{1}=0$. To marry up with Section II, let $D^{1}=d_{2}$. Then $N(P)$ reduces to $\operatorname{Max}\left(P-d_{2}, 0\right)$. That is, for $P$ $\leq d_{2}$, all of $P$ must be given to senlor debt-holders and there is none for new investors. On the other hand, for $P>d_{2}$, the firs can issue junior debt and give $\mathrm{P}-\mathrm{d}_{2}$ to new investors. 
In Section II, we proceeded on the assumption that nothing more sophisticated than simple debt/equity need be considered in many instances. It is time to justify that assumption. Obvlously, the four special cases given In Proposition 2 are examples where simple debt/equity is optimal. since in each case we are able to obtain the first best. Another case in which we can be sure that simple debt/equity is optlmal is where 1 and $y_{1}$ are deterministic:

Proposition 4

If 1 and $y_{1}$ are deterministic, then simple debt/equity is optimal.

Proof New Investment occurs iff $N(P) \geq 1-y_{1} ; 1 . e .$, In view of ( I4), Iff $P$ $z$ some critical value $P^{C}$. say. It follows that the optimum can be sustained by a simple debt/equity structure with $j_{2}=P^{c}-\left(1-y_{1}\right)$.

Q.E.D.

Note that Proposition 4 justifies our restriction to simple debt/equity In Examples 1 and 2 in Section II.

The following lemma presents a general sufficlent condition under which simple debt/equity is optimal when 1 and/or $y_{1}$ are stochastic. We assume that the distribution function $F\left(y_{1}, y_{2}, 1, r\right)$ satisfies: 
Condition $F F\left(y_{1}, y_{2}, 1, r\right)$ is continuously distributed, and the jolnt density function of $P=\left(r+y_{2}\right)$ and $N=\left(1-y_{1}\right) \rightarrow f(P, N)$ say -1 s strictly positive everywhere in the set $T E\left\{(P, N) \mid \underline{P} \leq P \leq \bar{P}_{;} 0 \leq N \leq P\right\}$, where $\underline{P}$ and $\bar{P}$ are respectively the minimum and maximum possible value of $r+y_{2}$.

Note that in choosing an optimal security structure $N(P)$, given the constraint (13), set $T$ is the only relevant part of the support of $\left.F(\}_{1}, y_{2}, 1, r\right)$. For $(P, N) \in T$, we define the following conditional expectation:

$$
K(P, N) \equiv E\left[r-1 \mid r+Y_{2}=P \& 1-y_{1}=N\right] .
$$

Key Lemma Assume Condition F holds. A : .18 -term security structure comprising simple debt $d_{2}$ and equity is optimal if the following condition holds:

Condition $K$ for any palr $\left(P^{*}, N^{*}\right) \in T$,

$$
\begin{aligned}
& K\left(P^{*}, N^{*}\right) \geq 0 \text { implles } \quad K(P, N)\left(\begin{array}{l}
> \\
z
\end{array}\right) 0 \quad \text { if } 0 \leq N^{-} N^{*}\left(\begin{array}{l}
< \\
\leq
\end{array}\right) P-P^{*} ; \\
& K\left(P^{*}, N^{*}\right) \leq 0 \text { implies } K(P, N)\left(\begin{array}{l}
< \\
\leq
\end{array}\right) 0 \quad \text { if } 0 \leq N^{*}-N\left(\begin{array}{l}
< \\
\leq
\end{array}\right) P^{*}-P .
\end{aligned}
$$


To help shed light on condition $K$, it is useful to rewrite $K(P, N)$ as $E\left[r-1 \mid y_{1}+y_{2}+r-1=P-N \& 1-y_{1}=N\right] ; v 1 z$. the expected return from the new investment project, conditional on the total net profit equalling $P-N$ and the amount of new financing equaliing $N$. If this conditional expectation is (strlctly) Increasing in $(P-N)$ and (Heakly) increasing in $N--1 . e$. if the project's profit rises with both the total net profit and the external financing requirement -- then condition $K$ will hold. 21 -

The lemma is proved in the Appendix. A rough intuition is as follows. $K(P, N(P))$ is the expected value of a marginal date 1 investment given a total date 2 payout of $P$. Condition $K$ implies that there is a cutoff value of $P$, say $P^{*}$. such that the expected value of a marginal date 1 investment is negative [resp. positive] if $\mathrm{P}<\mathrm{P}^{*}$ [resp. $\mathrm{P}>\mathrm{P}^{*}$ ]. Other things equal, then, one would llke to lower $N(P)$ for $P<P^{\circ}$, and ralse $N(P)$ for $P>P^{*}$. But we have to contend with the constraints (13) and (14). It should be clear that a slmple security structure comprising debt $d_{2}=P^{*}-N\left(P^{*}\right)$ and equity does a good job of balancing these goals (since $N^{\prime}(P)=0$ for $P<P^{*}$. and $N^{\prime}(P)=1$ for $\left.P>P^{*}\right)$.

The result follows from the lemma. 
Assume Condition F holds. A long-term security structure comprising simple debt $d_{2}$ and equity is optimal if

(1) 1 is deterministic;

and (2) $y_{1}$ is distributed independently of $y_{2}$ and $r$ :

and (3) $E\left[r \mid r+y_{2}=P\right]$ is strlctly increasing in $P$. for $P \leq P \leq \bar{P}$. 22

Proof Conditions (1) and (2) of the Proposition Jointly imply that $K(P, N)$ is independent of $N$. And together with Com.!ition (3), they imply that $X(P, N)$ is strictly increasing in $P$. Hence Condition $X$ is satisfied. Now apply the lemna.

Q.E.D.

Note that Condition (3) of Proposition 5 is very natural, and will hold (at least weakly) if $r$ and $r+y_{2}$ are affillated. The intuition behind the result is that, when 1 is fixed, new investment should not occur for low values of $r+y_{2}--$ since this signifles low $r$, on average; whereas the investment should'go ahead for high values of $r+y_{2}$. A simple debt/equity security structure implements this quite well.

Our final result concerns the opposite case to Proposition 5. 


\section{Proposition 6}

Assume Condition $F$ holds. If

(1) $r$ is deterministic

and (2) $y_{2}$ is independent of $y_{1}$ and 1

and (3) $E\left(1 \mid 1-y_{1}=N\right)$ is strictly increasing in $N$, for $\underline{P} \leq N \leq \bar{P}$.

then it is optimal at date 0 to issue two classes of debt: a negligible amount of senior debt. With an option to borrow a finite amount of additional debt of the same seniority at date $1\left(d_{1} \cong 0, \Delta d_{1}>0\right)$; and a large amount of a second class of debt with no option to borrow any more $\left(d_{2}=\infty, \Delta d_{2}=0\right)$.

In a sense the optimal security structure In Proposition 6 is the obverse of slmple debt/equity: the manager can ralse the first $\Delta d_{1}$ of any $P$. but no more $\left(N(P)=\min \left(P, \Delta d_{1}\right)\right)$. The intultion is that, given a fixed $r$. low/high values of 1 represent goodbad investment opportunltles and should be encouraged/discouraged. To this end, the manager is given an "overdraft facility" of $\Delta d_{1}$.

We do not give a formal proof of Proposition 6, since it is similar to the proofs of the lemra and Proposition 5 -- with Condltion X replaced by: $K(P, N)$ Independent of $P$ and strictly decreasing in $N$, for $(P, N) \in T$. 


\section{Conclusions and Extensions}

In this paper, we have explored the role of long-term debt in preventing self-interested management from financing unprof Itable Investments. He have show that in those cases where simple debt and equity are optimal: the hlgher is the average profitability of a firm's new Investment project, the lower w11l be the level of long-term debt; and the hlgher is the average profitabllity of a firm's existing assets (assets in place), the hlgher wlll be the level of long-term debt. He have also shown that, In general. It is optimal for a firm to issue classes of debt of different senloritles, with covenants a'lloling (1lmited) dilution of each class. Finally, we have derived sufficient conditions for the additlonal flexibility afforded by different classes not to be useful; that is, for slmple debt and equity to be optlmal.

It should be noted that some of our predictions are novel. For example. a theory which trades off the tax beneflts of debt against the bankruptcy costs of debt would not distinguish between assets in place and new investments, and would predict a positive correlation between profitability and the debt level. In contrast, our theory explains the observed strong negative correlation between profitability and leverage (see Carl Kester (1986) and Hyers (1990)), as long as high profitabllity is assoclated with new projects; this is Myers" (1990) first "striking fact."23 Note that we can also explain Myers' second striking fact. Consider a company that for some reason - perhaps historical - has (relatively) little debt, and suppose the

company faces the threat of a hostlle takeover. Then, according to our theory, the managers may engage in a debt-equity swap - that is, borrow and use the proceeds to pay a dividend or buy back equity - in order to commit themselves not to undertake future (bad) Investments (thereby persuading shareholders 
not to tender to the raider). Under these conditions, increases In leverage and increases in market value will move cogecher. ${ }^{24}$

6.s noted in the Introduction, however, perhaps a more Important difference between our theory and most others in the IIterature is that other theories cannot explain the fact that flrms issue hard (senlor, nonpostponable) debt clalms, whereas our theory can explain thls.

An important assumption that we have made is that a firm cannot renegotlate with its claim-holders at date 1 when a new investment project becomes avallable. Note that, If renegotlation were costless, there would be no dlsadvantage in having hlgh debt since if the new project had positlve net present value the creditors would always be prepared to renegotiate their claims so as to allow the project to go ahead. Thus in a world of costless renegotiation. It would be optimal to have infinite (or very high) debt, in effect forcing the firm to return to the capital market -- or, to put it another way, to seek permission from its creditors -- for every new investment.

Such an extreme outcome is unrealistlc, and there are strong theoretical reasons why. Because investors are wealth-constralned and risk averse, a major còrporation will typlcally be financed by a slzable number of small investors, rather than just a small number of very large ones. But this means that free-rider and hold-out problems are $11 \mathrm{kely}$ to make renegotiation difficult. In particular, if the debt level is too high to allor 7 positive NPV project to take place, then whlle it is in the collective interest of creditors to forgive a portion of the debt, it is in 
any small credltor's Interest to refuse to forgive his share since the chance that his decision will affect the outcome is very small. 25 Thus in many cases one would expect the renegotiation process to break down and investment not to occur; moreover the evidence of Gilson et.al. (1990) suggests that renegotiation frequently does fall in practlce. 26

One possible way round the free-rlder problem is to include a provision In the initial debt contract that the aggregate debt level can be reduced as long as a majority of creditors approvi il.e. the majority's wishes are binding on the minority). It turns out that the Trust Indenture Act of 1939 makes such a provision lllegal in the U.S.for public debt. However, even if it were legal, there are strong theoretical reasons for thinking that it would not solve the problem. For majority rule to work well, Individual Investors must keep abreast of the firm's progress and have very good Information about a firm's Investment prospects. Thls is a very demanding requirement in a complex world where most of Investors' time is quite properly allocated to other activities. In other words, our assumption that the profitablitty of new investment is public information should not be taken literally -- it is meant to apply to the most sophisticated arbitrageur, rather than to the average investor. Thus to make the firm's investment decision depend on a majority vote of average investors would be rather like runing the firm by a not very well informed committee -- a procedure whose record of success historically has been less than outstanding. 27

For these reasons, our assumption that renegotiation is impossible does not seem an unreasonable theoretical simplification for companies with wldely-held debt. 
There are a number of possible extensions of the analysis. An obvious one is to increase the number of perlods. This raises at least two new -and far from stralghtforward - issues. First, in a multiperlod model. management faces the choice of raising capltal for investment today or walting to invest unt1l tomorrow. In order to declde which cholce is preferred, one needs to know how management trades off different slzes of empires at different moments in time. In other words, the multiperiod extension requires the specification of an intertemporal managerlal ut111ty function. whereas the two perlod model required only the assumption that management prefers more investment to less.

A second complication is that the interpretation of seniority becomes less clear-cut. To give an example: In what sense does a senlor debt claim issued at date 1 with a promise to pay one dollar at date 4 have prlority over a Junior debt claim 1ssued at date 2 which promises to pay one dollar at date 3? The answer is that it depends on whether the firm goes bankrupt. If it does, the first claim is sentor, but if it does not the second clalm may $b=$ senior because $1 \mathrm{t}$ is pald off flrst. In other words, the notion of seniority that we have analysed must be enlarged to encompass senlority in an intertemporal sense.

Finally, our analysis has completely ignored the role of shareholder voting and takeovers in a flrm's cholce of flnanclal structure. Yet voting and takeovers are lmportant restralning forces on wanagement. In future work It is desirable to develop a framework which permits a study of the interplay between debt and the market for corporate control as constraints on managerial behaviour. 


\section{FOOTNOTES}

*Department of Economics, Harvard University, Cambridge, MA 02138, and Department of Economics, London School of Economics, Houghton Street, London, WC2 2AE, England. This is a major revision of a previous paper, "A Theory of Corporate Financial Structure Based on the Seniority of claims." We are particularly grateful to Ian Jewitt for simplifying the proof of the Key Lemma in Section III. We would also like to thank Rabindran Abraham, Abhijit Banerjee, Dick Brealey, Lucien Bebchuk, Stu Myers, Fausto Panunzi, David Webb, two anonymous referees and an Associate Editor, Paul Milgrom, for helpful comments. They are, of course, not responsible for the views expressed here. Finally, we acknowledge financial support from the National Science Foundation, the LSE Suntory-Toyota International Centre for Economics and Related Disciplines, the olin Foundation, and the Center for Energy Policy Research at MIT. 
IMliton Harris and Artur Raviv (1991) survey these theorles. A more recent literature has vlewed debt as a way of shifting control rights from corporate insiders to security-holders in certain (bankruptcy) states of the world (see Phllippe Aghion and Patrlck Bolton (1992) and Ollver Hart and John Moore (1989. 1994)). Control-based theorles seem more applicable to smallish, entrepreneurlal flrms than to public companies (the focus of this paper); in the latter, managers or directors rarely have voting control even when the company is solvent.

2For detalls, see Hart (1993). A related polnt has been made by PhIlip Dybvig and Jaime Zender (1991).

${ }^{3}$ Clifford Smith and Jerold Warner (1979) found that in a random sample of elghty-seven public issues of debt reglstered with the Securities and Exchange Commission between January 1974 and December 1975, more than $90 \%$ of the bonds contained restrictions on the issuing of additional debt. Although the strength of such debt covenants declined during the 1980 s, it is still very common for nèw public debt issues to contain some restrictions on new debt. See Kenneth Lehn and Annette Poulsen (1991).

${ }^{4}$ See Sanford Grossman and Oliver Hart (1982). 
${ }^{5}$ Some formal analysis is provided by Rene Stulz (1990) and Guozhong Xie (1990).

${ }^{6}$ The trade-off between overinvestment and underinvestment has also been analyzed recently by Elazar Berkovitch and E. Han KIn (1990). Stulz (1990). Xie (1990), and Robert Gertner and David Scharfstein (1991). Stulz and Xie consider models in which high short-term debt is good in that it forces management to pay out funds, but bad because it leads to inefficient.

piecemeal liquidation in the event of default (with, in Stulz's case, a loss of investment opportunities); Stulz and Xle do not consider the role of long-term debt in preventing the firm from raising new capltal. Berkovitch and KIm and Gertner and Scharfstein do consider the role of long-term debt. but assume that managers act on behalf of shareholders: that is, management is (Implicitly) assumed not to be self-interested. As we have noted, if management is not self-interested, the first-best can be achieved by putting management on an approprlate incentive scheme and making all of the firm's debt junior and poscponable.

7For example, a statement in the corporate charter stipulating that management should invest if and only if $r \geq 1$ is unenforceable since a disinterested judge or jury would not know whether $r \geq 1$. A statement that management must pay out all earnings at date 1 (that 15 , all of $y_{1}$, whatever $y_{1}$ may be) is unenforceable for similar reasons. 
${ }^{8}$ If project financling were possible, the new investment.could be financed as a stand-alone entity, whose merlt could 're issessed by the market at date 1; and debt levels could be set very hlgh to prevent the manager using funds from the exlsting assets to subsidize investment. There are several reasons for ruling out project flnancling. First, it may be that 1 represents an Incremental Investment -- e.g.. malntalning or lmproving the existing assets -- and the final return $y_{2}+r$ is simply the overall return from the (single) project. Second, it may be that the same management team looks after both the old assets and the new project, and can use transfer pricling to reallocate profits between them; hence the market can keep track only of total profits. Finally, even if project-specific financing is feasible, il is not at all clear that managers w1ll want to flnance a project that is not part of their emplre since they will not enjoy the private benefits of control (on th1s, see Shan L1 (1993)).

9 He ignore more sophistlcated bankruptcy systems that try to preserve the flrm's golng-concern value; examples are US Chapter 11 or the procedure discussed In Ph1lippe Aghion et.al. (1992).

${ }^{10}$ Thls is in the splrit of the early managerlal 11 terature of H1llam Baumol (1959), Robln Marris (1964) and Ollver Hilllamson (1964), as well as of the later work of Jensen (1986). For emplrical support, see Gordon Donaldson (1984). 
11 We suppose that the manager has no (or little) Initial wealth and so cannot be charged up front for emplre-bullding benefits.

${ }^{12}$ This distingulshes our model from a "pure free cash flow model" of the Jensen (1986) varlety. In a pure free cash flow model, the manager always has further uses of company funds and so will squander each dollar of Investor returns that is not mortgaged to creditors. Thus in a free cash flow model the value of equity is zero. In contrast, in our model, as the reader will shortly see, the value of equity can be positive.

Note that this is not a critical difference between the two analyses since our main results would st1ll hold under the more extreme Jensen assumptions. A more Important difference between the models is that ours explicitly conslders the costs as well as the benefits of short and long-term debt.

${ }^{13}$ Both of these scenarlos are of course speclal. We belleve that the thrust of our analysls applies also to the case where management chooses financlal structure to maximize its own welfare. In the present three date model, this leads to the trivial outcome of no debt (management clearly prefers not to be under pressure from creditors). However, In a model with more periods management may 1ssue (senlor) debt vol'silly. since this may be the only way to ralse funds from Investors concerned that their claims may be diluted if management undertakes bad investments in the future. On this, see Jeffrey Zwelbel (1993). 
14 Notice that we are rulling out the possibllity of negative debt. For example, a negative $d_{1}-$ in effect a pre-arranged boost to $y_{1}-$ allows the manager to make an Investment $w 1$ thout the need to $g \circ$ to the market at date 1. even when $y_{1}<1$. Thls may be helpful if the profitable investments are small ones. A negative $d_{1}$ may be hard to lmplement, however. It may be Impossible to arrange for dispersed creditors to pay in money at date 1; and If the manager is given the money at date $O$ he may use it to make an unprofitable date 0 investment.

${ }^{15}$ Strictly speaking, we ought to truncate the distributions of $y_{2}$ and $r$ so that they are nonnegative. See our 1990 Working Paper for further detalls.

${ }^{16}$ Example 1 is easily generallsed to allow for correlation between $y_{2}$ and $r$. If their correlation coefficlent is $p$, then the optimal $d_{2}$ is given by

$$
\mathrm{d}_{2}=y_{1}+\mu_{2}-\left(\frac{\sigma_{2}^{2}+\rho \sigma_{2} \sigma_{r}}{\sigma_{r}^{2}+\rho \sigma_{2} \sigma_{r}}\right)\left[\mu_{r}-1\right] .
$$

Note that the denominator $\sigma_{r}^{2}+\rho \sigma_{2} \sigma_{r}$ ir rositive from the second order condition. Thus, provided the numerator $\sigma_{2}^{2}+\rho \sigma_{2} \sigma_{r}$ is positive -- which it w11l be unless $\left(-\sigma_{r} / \sigma_{2}\right)<\rho \leq\left(-\sigma_{2} / \sigma_{r}\right)-$ the comparative statics results reported in the text continue to hold. 
${ }^{17}$ One can think of even more general securitles. One possiblilty is that $O(P)$ could be conditioned on the amount of money ralsed at date 1 . However, our preliminary investigations suggest that the extra degree of freedom would not help.

Another possibllity is that $O(P)$ could be sensitive to the market value of securitles. The difficulty with this is that there is a tricky bootstraps effect: market values are affected by the manager's actlons, which are in turn constrained by the form of $O(P)$.

${ }^{18}$ It is stralghtforward to confirm that Proposition 1 continues to apply. even when more sophlsticated long-term securitles are admitted. That is, there is no role for short-term securitles -- like short-term debt $d_{1}$-- which promise to pay out at date 1 .

${ }^{19}$ The argument is as follows. Suppose $\mathrm{P}^{-}<\mathrm{P}^{+}$and $N\left(\mathrm{P}^{+}\right)-N\left(\mathrm{P}^{-}\right)>\mathrm{P}^{+}-\mathrm{P}^{-}$. Then the flrm's date $O$ market value will not change if $N\left(P^{-}\right)$is raised to $N\left(P^{+}\right)-P^{+}+P^{-}$. The reason 15 that if $y_{2}+r=P^{-}$and $N\left(P^{-}\right)<1-y_{1} \leq N\left(P^{+}\right)$ $-P^{+}+P^{-}$. the manager can ralse $\left(1-s_{1} j^{+}+\left(P^{+}-P^{-}\right)\right.$dollars from the market. invest 1 in the project and save the remalning $\left(P^{+}-P^{-}\right)$. This yields a total date 2 return of $P^{+}$, out of which the manager can repay new security-holders up to $N\left(\mathrm{P}^{+}\right) \geq 1-y_{1}+\left(\mathrm{P}^{+}-\mathrm{P}^{-}\right)$. Again this argument can be extended to show that date 0 market value w11l be unchanged if $N(P)$ is replaced by $\sup \left(\left(N\left(P^{+}\right)-P^{+}+P\right) \mid P^{+} \geq P\right)$. This ylelds a function $N(P)$ whose slope is less than or equal to one. 
${ }^{20}$ For a discussion of covenants used in practlce, see Smith and Warner (1979) and Lehn and Poulsen (1991). For an example of a bond prospectus (Potomac Electric Power Co.) with essentially the form of our standard debt/equity package, see Brealey and Myers (1988), pp 591-599.

${ }^{21}$ We are grateful to a referee for pointing this out.

22 Note that there is no Inconsistency between Proposition 5 and Example 3. If 1 is deterministic and $y_{1}=0, r \equiv g\left(y_{2}\right)$, then there is indeterminacy in the optimal security structure.

23 ilusured profitability reflects the profitablilty of assets in place. However. If the profitabilities of assets in place and new investments are positively correlated, then measured profitability may serve as a proxy for the profitability of new investments.

${ }^{24}$ For detalls, see Hart (1993). Other bonding theorles, such as those in Grossman and Hart (1982) and Jensen (1986), can also explain this observation.

${ }^{25}$ See, for example, Gertner and Scharfstein (1991). 
${ }^{26}$ In a study of the companies 11sted on the New York and American Stock Exchanges that were in severe financlal distress during 1978-1987, Gilson et.al. (1990) found that workouts falled more of ten than so percent of the time, and were more likely to fall the larger the number of creditors. See also Gilson (1991).

${ }^{27}$ To put 1 another way, to the extent that (dispersed) creditors are poorly informed, any debt forglveness is likely to be insensitive to the ex post reallzations of $y_{1}, y_{2}, r$ and 1 ; that is, debt forglveness wlll be approximately a flxed amount $d^{\prime}$. But then the same outcome could be achleved by setting the origlnal debt level equal to $d_{2}-d^{\prime} ; 1 . e$, debt forglveness serves no useful role. 
In this Appendix, we prove Proposition 3 and the Key Lemma.

\section{Proof of Proposition 3}

Part (1) follows immediately from an inspection of program ( 6 ).

If a small $\varepsilon>0$ is added to every reallzation of 1 , the left hand side of $(7)$ becomes

$$
\begin{aligned}
& E\left[r-i-\varepsilon \mid y_{1}+y_{2}+r-1-\varepsilon=d_{2}\right]=-\varepsilon+E\left[r-1 \mid y_{1}+y_{2}+r-i=d_{2}+\varepsilon\right] \\
& <E\left[r-1 \mid y_{1}+y_{2}+r-1=d_{2}\right]=0 \text { by the right hand inequality in } \\
& \text { Condition } \mathrm{C} \text { and by ( } 7 \text { ). }
\end{aligned}
$$

Hence, from the left hand inequality in Condition $c$. It follows that the new debt level strictily exceeds $d_{2}$. An identical argument can be used for the case where $\varepsilon>0$ is subtracted from every realization of $r$.

Q.E.D. 
Let $\mathrm{C}$ be the class of admissible security structures $\mathrm{N}$ satisfylng (13) and ( 14$)$. and let $V(N)$ denote the integral in (12). Note that $C$ is convex: $\lambda N+(1-\lambda) M \in C$ for any $N, M \in C$ and any $0 \leq \lambda \leq 1$. If $N$ is an optlmal security structure, then $\partial V(\lambda N+(1-\lambda) M) / \partial \lambda \approx 0$ at $\lambda=1$. Carrying out the differentiation,

(A. 1)

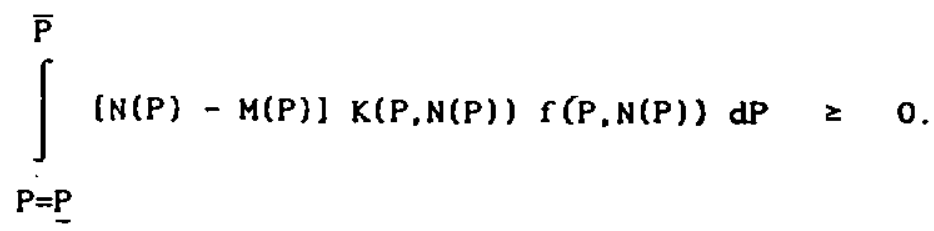

where, by Condition $F$, the joint density $f(P, N(P))>0$ for $\underline{P} \leq P \leq \bar{P}$.

Let $P^{*}=$ inf $\{P \mid P \leq P \leq \bar{P} ; K(P, N(P))>0\}$. Condition $K$ implies that $K(P, N(P)) \leq 0$ for all $\underline{P} \leq P<P^{*}$, and $K(P, N(P)) \geq 0$ for all $P^{*}<P \leq \bar{P}$.

Suppose $N(P)$ is not a simple debt/equity security structure in the relevant domain ( $v i z ., P \leq P \leq \bar{P})$. Then construct a security structure $M$ comprising simple debt $d_{2}$ and equity, where

$$
d_{2}=P^{*}-N\left(P^{*}\right)
$$

(We know that this $d_{2} \geq 0$, since $N$ satisfies $(13$.$) ) That is, M\left(P^{*}\right)=N\left(P^{*}\right)$. In the light of the fact that $N$ satisfies $(13)$ and $(14), M(P) \leq N(P)$ for 
all $\underline{P} \leq P<P^{*}$, and $M(P)<N(P)$ for all $P^{*}<P \leq \bar{P}$. Thus the left hand side of (A.1) is at most zero.

Moreover, since $N \neq M$, there must be some open interval $S \subset[\underline{P}, \bar{P}]$. not containing $P^{*}$, such that, for all $P \in S$, both (1) $N(P) * M(P)$, and (11) $N\left(P^{*}\right)$ - $N(P) \neq P^{*}-P$. From Condition $K,(11)$ Implies $K(P, N(P)) \neq 0$ for all $P \in S$. But this means that the left hand side of (A.1) is in fact strictly negative; a contradiction. Hence a simple debt/equity security structure is optimal.

Q.E.D. 


\section{REFERENCES}

Aghion, Philippe, and Bolton, Patrick. "An Incomplete Contracts Approach to Financial Contracting." Review of Economlc Studies, July 1992, $\underline{59}(3)$, pp. 473-94.

Aghion, Philippe; Hart, Oliver; and Moore, John. "The Economlcs of Bankruptcy Reform." Journal of Law, Economics and Organlzation, October 1992, $\underline{8}(3)$, pp, 523-46.

Allen, Franklin, and Gale, Douglas. "Opiiral Security Deslgn." Revlew of Financial Studies, Fall 1988, 1(3), pp. 229-63.

Baumol, William. Business Behavlor and Growth. New York: Macmlllan Company, 1959.

Berkovitch, Elazar, and Kim, E. Han, "Financlal Contracting and Leverage Induced Over- and Under-Investment IncentIves." Journal of Finance, July 1990, 45(3), pp. 765-94.

Brealey, Richard, and Myers, Stewart. Principles of Corporate Finance. New York: McGraw Hill, Third Edition, 1988.

Donaldson, Gordon. Managing Corporate Wealth. New York: Praeger, 1984. Dybvig, Philip, and Zender, Jaime. "Capital structure and Dividend Irrelevance with Asymmetric Information." Revtew of Financlal Studies, 1991, 4(1), pp. 201-19.

Gertner, Robert, and Scharfstein, David. "A Theory of Workouts and the Effects of Reorganization Law." Journal of Finance. September $1991,46(4)$, pp. 1189-1222.

Gilson, Stuart; John Kose; and Lang, Larry. "Troubled Debt Restructurings: An Empirical Study of Private Reorganization of Firms in Default." Journal of Financial Economics, October 1990, 26 (2), pp. 315-53. 
Gilson, Stuart. "Managing Default: Some Evidence on How Firms Choose Between Workouts and Chapter 11." Journal of Applied Corporate Finance, Summer $1991,4.4$ p. $62-70$.

Grossman, Stanford, and Hart, Oliver. "Corporate Financial Structure and Managerlal Incentives," in J. J. McCall, ed, "The Economics of Information and Uncertainty. Chicag?. IL: University of Chicago Press, 1982, pp. $107-40$.

Harris, Milton, and Raviv, Artur. "The Theory of Capital Structure." Journal of Finance, March 1991, 46 (1), pp. 297-355.

"Financial Contracting Theory," in J.J. Laffont, ed., Advances in Economic Theory: Sixth World Congress, Vol. II. Cambridge: Cambridge University Press, 1992, pp. 64-150.

Hart, Oliver. "Theories of Optimal Capital Structure: A Managerial Discretion Eerspective." in Margaret Blair, ed. The Deal Decade: What Takeovers and Leveraged Buyouts Mean for Corporate Governance. Waskington. DC: The Brookings Institution, 1993, pp. 19-53. - and Moore. John. "Default and Renegotlation: A Dynamic Model of Debt." University of Edinburgh Discussion Paper, University of Edinburgh, August 1989.

- "A Theory of Corporate Financial Structure Based on the Seniority of Claims." Department of Economics MIT Working Paper No. 560. Cambridge, MA, 1990.

. "A Theory of Debt Based on the Inalienability of Human Capital." Quarterly Journal of Economics, forthcoming in November 1994. 
Jensen, Michael. "Agency Costs of Free Cash Flow, Corporate Finance and Takeovers." American Economic Review, May 1986, 76(2), pp. 32329. , and Meckling, William. "Theory of the Firm: Managerial Behavior, Agency Costs and Ownershij Structure." Journal of Financial Economics, October 1976, 3(4), pp. 305-60.

Kester, Carl. "Capital and Ownership Structure: A Comparison of United States and Japanese Manufacturing Corporations." Financlal Management, Spring 1986, pp. 5-16.

Lehn, Kenneth and Poulsen, Annette. "Contractual Resolution of BondholderShareholder Conflicts In Leveraged Buyouts." Journal of Law and Economics, October 1992, $\underline{34}(2)$, Pp. 645-74.

Leland, Hayne, and Pyle, David. "Informational Asymetries, Financial Structure, and Financial Intermediation." Journal of Finance. May 1977, 32(2), ṕp. $371-87$.

Li, Shan. "Essays on Corporate Governance and Finance." Ph.D. dissertation, MIT, 1993.

Marris, Robin. The Economic Theory of Managerial Capitalism. Illinois: Free Press of Glencoe, 1964.

MilF, - Pm, Paul, and Weber, Robert. "A Theory of Auctions and Competitive Bidding." Econometrica, September 1982, 50(5), pp. 1089-112.

Miller, Merton. "Debt and Taxes." Journal of Finance, May 1977, 32(2), pp. $261-75$.

Modigliani, Franco, and Miller, Merton. "Corporate Income Taxes and the Cost of Capital: A Correction." American Economic Revlew, June 1963. $\underline{53}(3)$, pp. $433-43$ 
Myers, Stewart. "Determinants of Corporate Borrowing." Journal of Financial Economics, November 1977, $\underline{5}(2)$, pp. 147-75. . "Still Searching for Optimal Capital Structure," In R. Kopcke and E. Rosengren, eds., Are the Distinctions Between Debt and Equity Disappearing?. Federal Reserve Bank of Boston Conference Series No. 33. Boston, 1990. , and Majluf, Nicholas. "Corporate Financing and Investment Decisions When Firms Have Information That Investors Do Not Have." Journal of Financial Economics, June 1984, 13(2), pp. 187-221.

Ross, Stephen. "The Determination of Financial structure: The Incentive Signalling Approach." Bell Journal of Economics, Spring 1977. 8(1), pp. $23-40$.

Srich, Clifford, and Warner, Jerold. "On Financial Contracting: An Analysis of Bond Covenants." Journal of Financial Economics, June 1979. ?(2), pp. $117-61$.

Stiglitz, Joseph. "On the Irrelevance of Corporate Financlal Policy." American Economic Review. December 1974, 64(6), pp. 851-66.

Stulz. René. "Managerial Discretion and Optimal Financing Policies." Journal of Financial Economics, July $1990,26(1)$, pp. 3-27.

Williamson, Oliver. The Economics of Discretionary Behavior: Managerial Objectives in a Theory of the Firm. Englewood cliffs. NJ: Prencice Hall, 1964.

Xie, Guozhong. "Essays on the Theory of the Firm." Ph.D. dissertation, MIT. 1990.

Ziteibei, Jeffrey $H$. "A Control Theory of S"rnamic Capital Structure." Mimeo, Stanford University Graduate School of Business, 1993. 


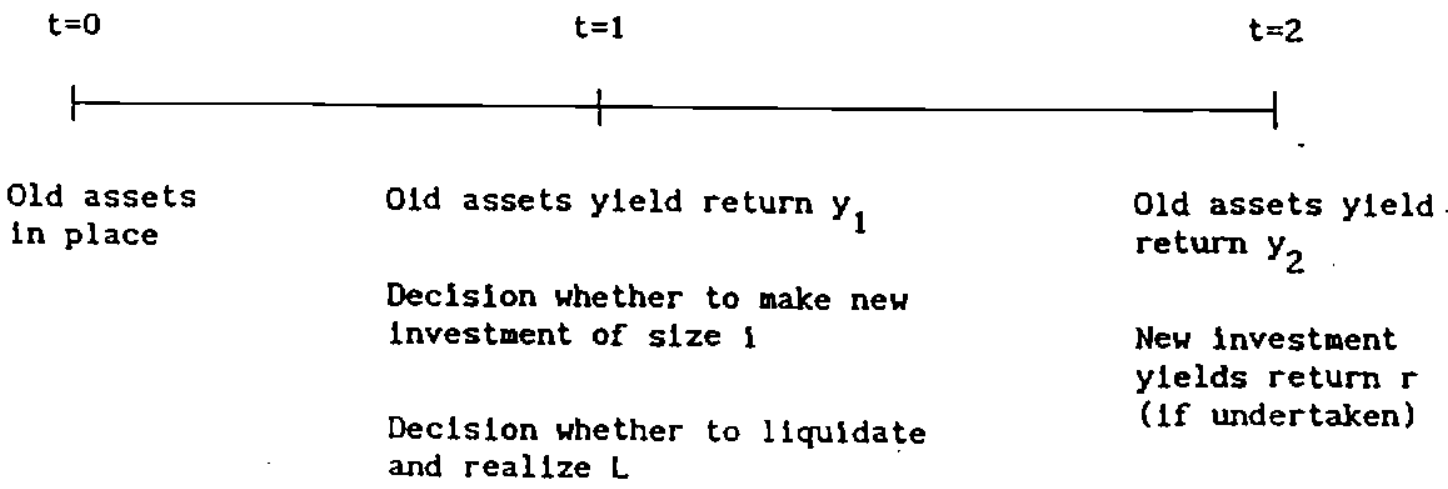




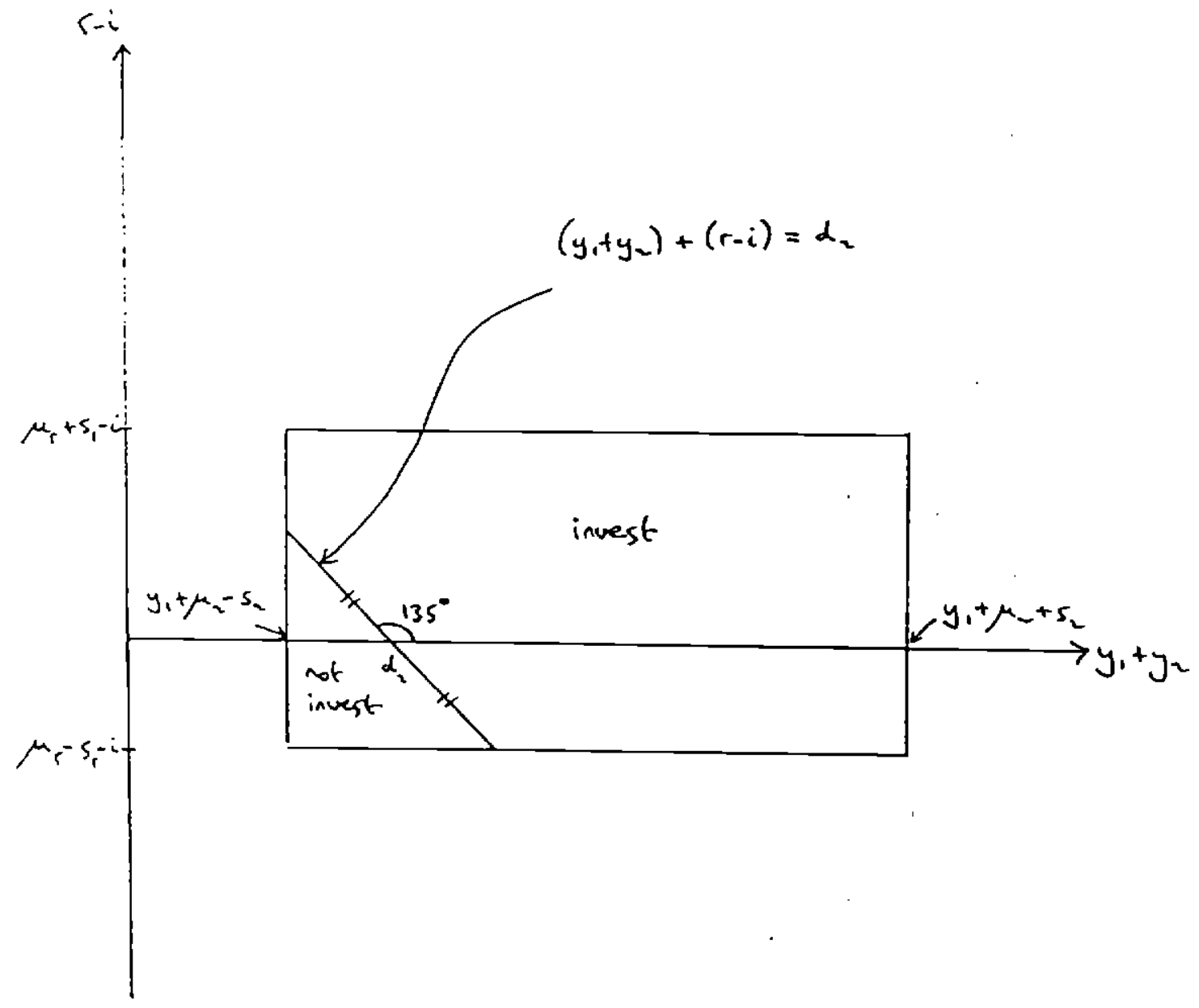

F1gure 2 


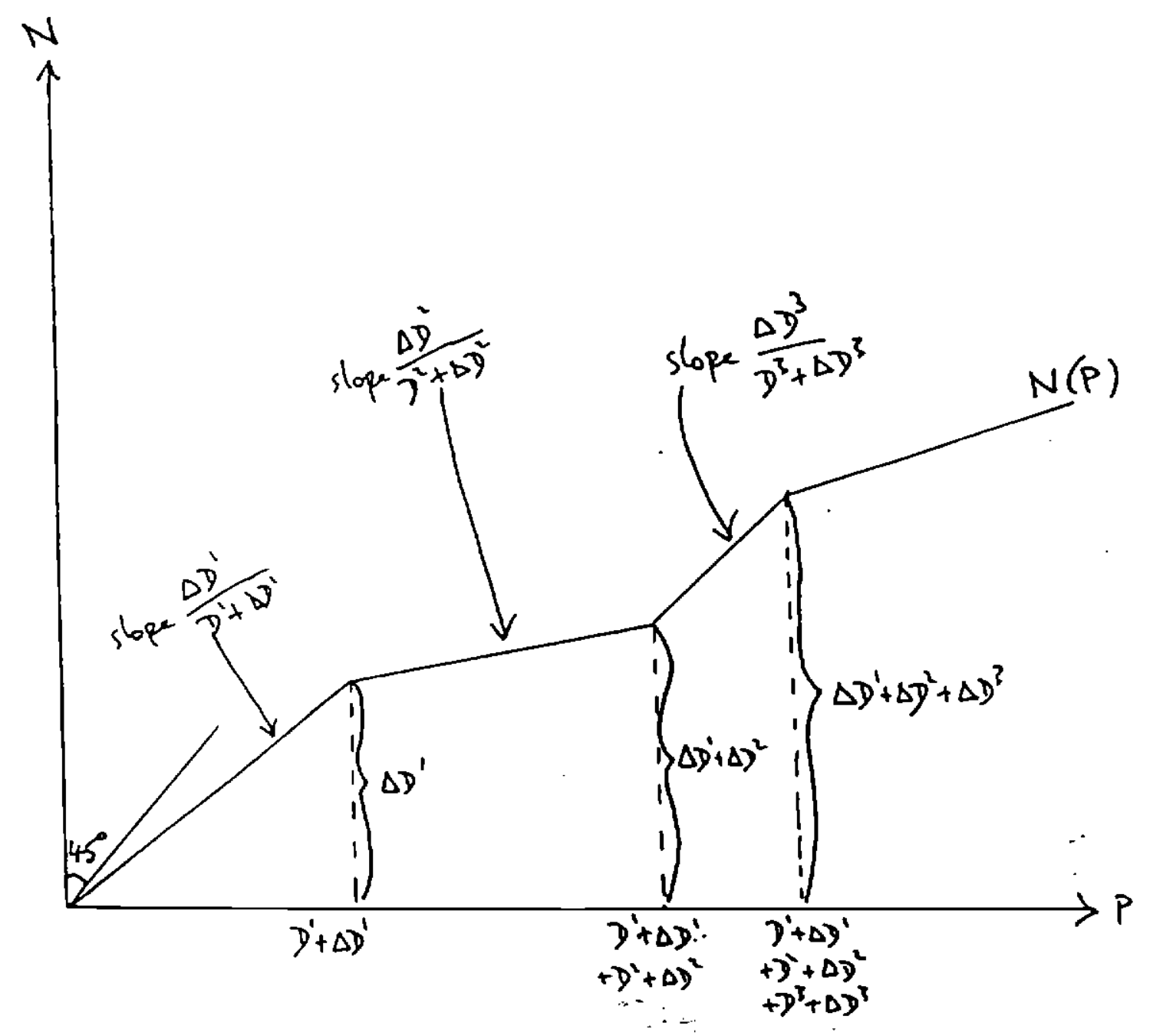

Figure 3 